\title{
Applying local knowledge to rangeland management in northern Mongolia: do 'narrow plants' reflect the carrying capacity of the land?
}

\author{
Kaoru Kakinuma ${ }^{1^{*}}$ and Seiki Takatsuki ${ }^{2}$
}

\author{
* Correspondence: 4119233127@ \\ mail.ecc.u-tokyo.ac.jp \\ ${ }^{1}$ Department of Ecosystem Studies, \\ Graduate School of Agricultural and \\ Life Sciences, University of Tokyo, \\ 1-1-1 Yayoi, Bunkyo-ku, Tokyo \\ 113-8657, Japan \\ Full list of author information is \\ available at the end of the article
}

\begin{abstract}
Investigating traditional ecological knowledge (TEK) by the scientific approach is a useful way to develop sustainable rangeland management. Numerous trials have been done on plant species compositions and biomass, but little testing has been done on the TEK of plant productivity and nutrient values, which are important for proper rangeland management. In this study, we tested the TEK of pastoralists living in Bulgan, northern Mongolia, regarding plant productivity and nutrient values. We examined biomass, growth form, plant productivity, and crude protein amounts along grazing gradients. The results showed that biomass declined and the number of erect-form plants decreased as grazing intensity increased, although plant productivity and crude protein amounts did not differ along the grazing gradient. This indicates that the pastoralists' evaluation of pastures dominated by narrow plants (Mongolian: nariin ovs) accurately reflects the productivity of the land, suggesting that their evaluation is reasonable in terms of the carrying capacity. This assessment of the ecological status of Mongolian rangelands provides a foundation for ecologically sound and culturally appropriate rangeland management.
\end{abstract}

Keywords: Forage nutrition, Grazing gradients, Local knowledge, Nomadic herders, Plant productivity, Vegetation changes

\section{Introduction}

Mongolia is covered by grasslands that have been used to support nomadic life for centuries. During the Soviet era, pasture use was managed, while seasonal mobility was enforced and facilitated by large herd-owning institutions (Fernandez-Gimenez 2002). The collectives regulated and supported the seasonal movement of pastoralists through subsidized transportation, auxiliary labour, and water developments. After the collapse of the Soviet Union, the livestock population increased as Mongolia transitioned to a free-market economy and private livestock ownership was permitted beginning in the early 1990s (Humphrey and Sneath 1999). Once the collectives were dismantled, there was no longer a formal regulatory institution to govern pasture use (Fernandez-Gimenez 2000). The increase in the number of livestock and the decrease in support for seasonal movement have resulted in rangeland degradation, particularly around villages and towns (e.g. Okayasu et al. 2007), where there is easy access to the market.

(c) Kakinuma and Takatsuki; licensee Springer. This is an Open Access article distributed under the terms of the Creative Commons Attribution License (http://creativecommons.org/licenses/by/2.0), which permits unrestricted use, distribution, and reproduction in any medium, provided the original work is properly cited. 
Kakinuma et al. (2008) reported that local pastoralists in the north-central part of Mongolia perceive heavily grazed areas as good pasture for grazing. Previous studies have shown that the prevalence of small graminoids increases as grazing intensity is intensified in mountain-steppe or forest-steppe regions (e.g. Fernandez-Gimenez and Allen-Diaz 2001; Kakinuma et al. 2008). Local pastoralists in the north-central region call these graminoids nariin ovs, meaning 'narrow plants', and perceive them as good forage for sheep and goats. They consider heavily grazed places as suitable for additional grazing because of the dominance of narrow plants (Kakinuma et al. 2008) and do not seem to perceive such heavy grazing as negative.

The importance of traditional ecological knowledge (TEK) in rangeland management is widely recognized (Berkes et al. 2000), and many studies have tried to validate TEK by scientific methods (e.g. Milton et al. 1998; Fernandez-Gimenez 2000; Oba and Kaitira 2006; Reed et al. 2008). Disagreements are sometimes found between TEK and scientific knowledge. For example, one study showed that perennial grasses decreased while shrubs increased according to grazing pressure, which was regarded as 'degradation' by scientists. However, local pastoralists evaluated this as positive because they knew that cattle preferably fed on the shrubs (Katjiua and Ward 2007). This suggests that for the effective management of grazing lands, it is necessary and important to reach compromise on such disagreements between local people and scientists (Fernandez-Gimenez 2000; Briske et al. 2008). Such disagreements seem to result from the fact that grasslands were evaluated based on only structural aspects, such as species compositions or biomass (e.g. Milton et al. 1998; Fernandez-Gimenez 2000; Oba and Kaitira 2006; Reed et al. 2008), while plant productivity and nutritional values were not sufficiently evaluated.

In this study, we examined the compositions, productivity, and nutritional values of plant communities along a grazing gradient in order to test the pastoralists' TEK of grazing lands by the scientific approach. We studied plant communities along a grazing gradient and compared the following characteristics: (1) compositions of the plant communities according to growth form (Gimingham 1951); (2) productivity of these plant communities, which was measured by using the movable-cage method; and (3) protein content of the plants, because protein is important for livestock nutrition (Riney 1982).

\section{Material and methods}

\section{Study area}

The study area is located near Bulgan province $\left(48^{\circ} 57^{\prime} \mathrm{N}, 103^{\circ} 21^{\prime} \mathrm{E}\right)$ in the north-central part of Mongolia. We choose Bulgan province as the study area because the impact of grazing on vegetation is clearly visible (due to relatively high and stable rainfall) and because the population of livestock had recently increased (Figure 1). Therefore, the risk of land degradation is relatively high in Bulgan province. The number of households and livestock decreased during the period 2009 to 2010 due to a winter disaster (a $d z u d$ in Mongolian). However, the $d z u d$ occurred after data collection in the present study.

The mean annual temperature in the study area is $-1.0^{\circ} \mathrm{C}$, and the range of mean monthly temperatures from 1961 to 2008 was $-20.3^{\circ} \mathrm{C}$ to $16.4^{\circ} \mathrm{C}$ (Institute of Meteorology and Hydrology of Mongolia). The mean annual precipitation from 1961 to 2008 was $328.2 \mathrm{~mm}$ (Table 1). In 2008, the year this study was conducted, the annual precipitation was $310.3 \mathrm{~mm}$ (Table 1). Monthly, growing-season, and annual rainfall during 


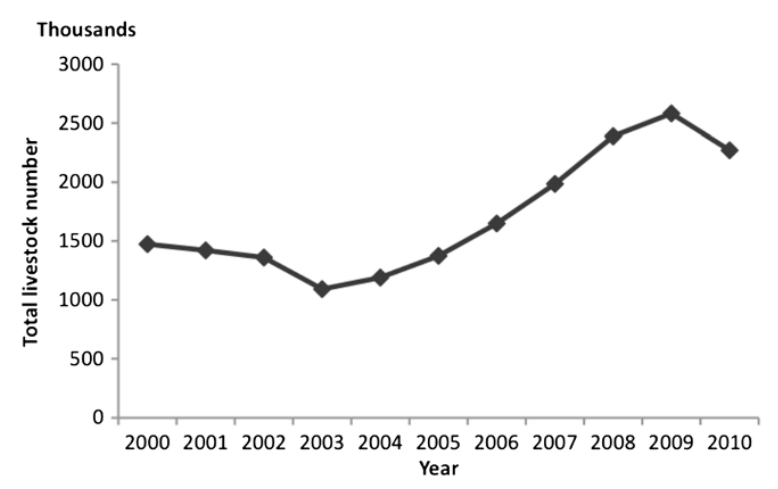

Figure 1 The number of livestock at the study sites from 2000 to $\mathbf{2 0 1 0}$. Data were provided by the Department of Statistics in Bulgan province.

the study period are also shown in Table 1 . The coefficient of variation $(\mathrm{CV})$ of the annual precipitation is $21.3 \%$. According to Ellis (1995), in regions where the annual precipitation is less than $250 \mathrm{~mm}$ and the CV exceeds 33\%, precipitation is variable and the vegetation dynamics is strongly affected by precipitation. Therefore, we regarded Bulgan as having relatively stable precipitation and rainfall variability as having little impact on the vegetation dynamics.

The vegetation is of the forest-steppe type (Hilbig 1995). Vegetation in the region is dominated by the grasses Festuca rubra and Poa attenuata, the sedge Carex duriuscula, and the forbs Galium verum and Artemisia frigida. The main livestock include sheep, goats, cattle, and horses. The pastoralists of Bulgan tend to stay in the valleys during summer, and they stay in the foothills during winter in order to avoid cold winds (Morinaga et al. 2008). The pastoralists move their herds only two or three times a year and at distances usually less than $3 \mathrm{~km}$, which is less frequent and a shorter distance than in arid areas (Humphrey and Sneath 1999). The grasslands of the forest-steppe zone are productive and the yearly variations in productivity are small, which permits such infrequent and short-distance movements. In contrast, in arid areas, long-distance movement is necessary because of the high frequency of drought (Humphrey and Sneath 1999).

\section{Grazing intensity}

The grazing gradient, or piosphere, approach (Andrew 1988) assumes that grazing intensity declines with increasing distance from a fixed water point. Our sampling sites were located along a grazing gradient, as has been done in other semiarid rangeland ecosystems (e.g. Fernandez-Gimenez and Allen-Diaz 2001; Reed et al. 2008; Sasaki

Table 1 Monthly, growing-season (June and July), and annual rainfall $(\mathrm{mm})$ at the Bulgan study site

\begin{tabular}{lccccccccccccccc}
\hline & Jan. & Feb. & Mar. Apr. May June July & Aug. Sept. & Oct. Nov. Dec. Growing Annual \\
season
\end{tabular}

Data were provided by the Institute of Meteorology and Hydrology of Mongolia. 
et al. 2008). We established five sites $(0.6,1.2,1.8,2.4$, and $3.0 \mathrm{~km})$ from a water point, with three replicate sites for each distance (Figure 2). We selected the $3.0-\mathrm{km}$ site as the farthest point because there were few livestock dung droppings at this point, suggesting little use by livestock and consequently low grazing effects. We then set the sites evenly at intervals of $0.6 \mathrm{~km}$. We chose to set the grazing gradients and replicate the sites within the same general landscape type, rather than setting them in different directions from the water source and introducing additional variability.

\section{Vegetation sampling}

We designated ten $1 \mathrm{~m} \times 1 \mathrm{~m}$ quadrat plots at each of the 15 sites (Figure 2). The sampling period was from 1 July to 28 July 2008. In each quadrat, we estimated the coverage (\%) of each plant species and noted its growth form. Grazing effects were partly evaluated by changes along the gradient in the prevalence of four growth forms (Gimingham 1951): tussock, branched, erect, and rosette. Typical narrow plants, including C. duriuscula, F. rubra, Koeleria macrantha, and Cleistogenes squarrosa, are regarded as good forages by local pastoralists (Kakinuma et al. 2008), and they have a tussock growth form. After estimating coverage, we clipped off all the aboveground parts of the plants in each plot, air-dried the samples for two weeks, and weighed them to the nearest $0.1 \mathrm{~g}$ to obtain a measurement of standing biomass.

The aboveground productivity during one month in summer was measured by using the movable-cage method (e.g. McNaughton et al. 1996). On 8 July 2008, we placed five grazing-proof cages at each of the three $0.6-\mathrm{km}$ sites (heavy grazing) and five grazingproof cages at each of the three 3.0-km sites (light grazing), after clipping off the vegetation at ground level. The cage size was $1 \mathrm{~m} \times 1 \mathrm{~m} \times 0.5 \mathrm{~m}$ (height). To obtain the baseline level for the productivity measurements (G7), all of the aboveground vegetation from five $1 \mathrm{~m} \times 1 \mathrm{~m}$ plots at each of the 0.6 - and 3.0-km sites was sampled on 8 July 2008 and weighed, as described above; these plots were then left unprotected. All the plants inside the cages (ungrazed) and in $1 \mathrm{~m} \times 1 \mathrm{~m}$ unprotected (grazed) plots at each site were clipped off at ground level after 31 days (8 August 2008), air-dried for two weeks, and weighed. The removal of vegetation by grazing in August (R8) was calculated as follows: R8 = U8 - G8, where U8 and G8 are the ungrazed and grazed

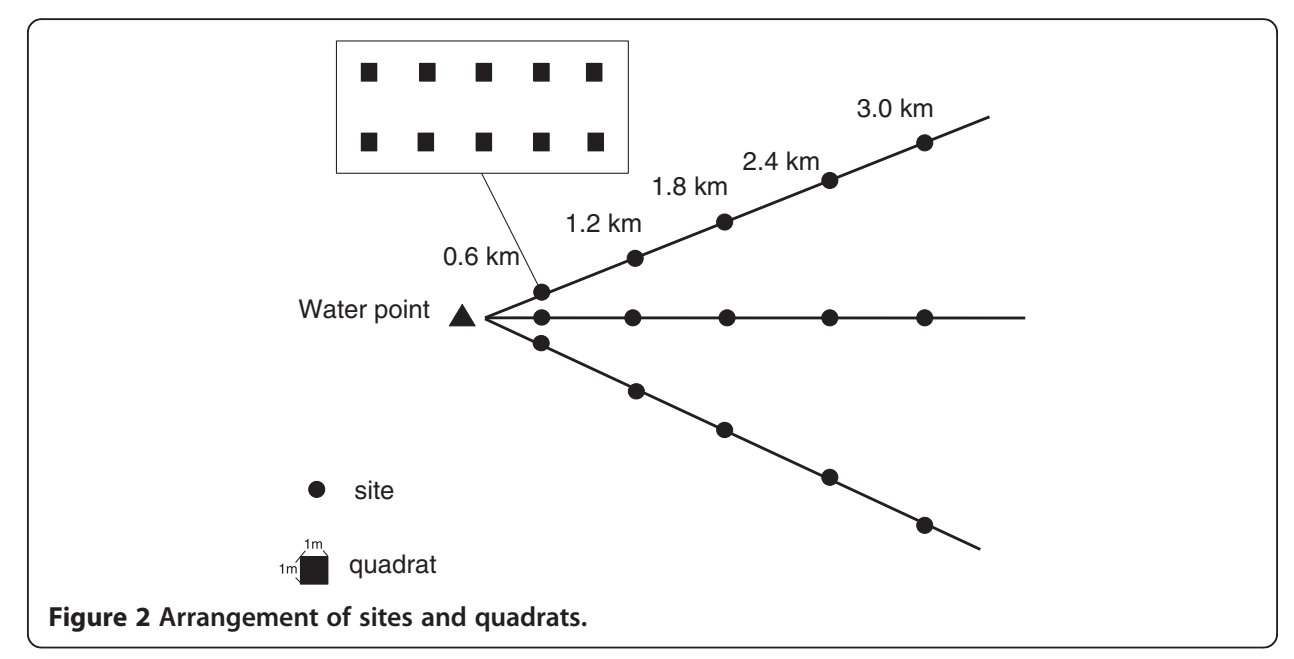


biomass in month 8 (August), respectively. Productivity in August (P8) was calculated as follows: P8 $=$ U8 - G7.

We determined the amount of crude protein $(\mathrm{CP})$ in each sample based on its nitrogen content (\% of total dry weight). The plants in each sample were mixed, dried, and milled. The nitrogen concentration was determined by the Kjeldahl procedure in which forage samples were digested with sulfuric acid and catalysts (mixture of copper sulphate and potassium sulphate). CP concentration was calculated by multiplying total nitrogen concentration (\% of total dry weight) by 6.25 . The total amount of CP in each plot was calculated by multiplying CP content (\%) by biomass $\left(\mathrm{g} / \mathrm{m}^{2}\right)$.

\section{Data analysis}

Because the data were not normally distributed, the coverage by each growth form was compared among the five distances from the water point with the Kruskal-Wallis test. Coverage by nariin ovs (narrow plants) was compared among the five distances from the water point with the Kruskal-Wallis test because the data were not normally distributed. When the Kruskal-Wallis test revealed differences in coverage of nariin ovs along the gradient, we used the Bonferroni multiple comparison test to detect which sites had differences. Standing biomass was compared among the five distances from the water point with the Kruskal-Wallis test because the data were not normally distributed. Likewise, when the test revealed differences, the Bonferroni multiple comparison test was used to detect which sites had differences. The productivity and vegetation removal by livestock were compared between the 0.6 - and $3.0-\mathrm{km}$ distances by the Wilcoxon signed-rank test, with the significance level set at $P=0.05$. Analysis of variance (ANOVA) was used to compare the CP amounts $\left(\mathrm{g} / \mathrm{m}^{2}\right)$ among the five distances.

\section{Results}

The coverage by plants with the erect and branched forms decreased significantly $(P<0.05)$ as the distance between the plots and the water point decreased (i.e. as grazing intensity increased; Figure 3; Table 2). Species with the erect form included perennial forbs such as Bupleurum bicaule and G. verum, and species with the branched form included perennial forbs such as Leontopodium leontopodioides and A. frigida. The overall coverage by plants with the rosette and tussock forms did not change as the distance from the water point decreased, though the coverage of certain species with these forms did change significantly (Figure 3; Table 2). Species with the rosette form included perennial forbs such as

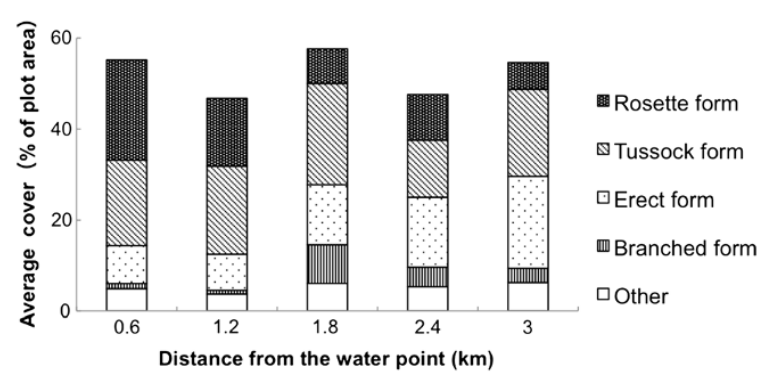

Figure 3 Coverage by each plant growth form along the grazing gradient. 
Table 2 Results of Kruskal-Wallis test used to examine change in coverage and standing biomass along grazing gradient

\begin{tabular}{lllll}
\hline & Growth form & Kruskal-Wallis $\boldsymbol{X}^{\mathbf{2}}$ & d.f. & $\boldsymbol{P}$ \\
\hline Cover of $P$. acaulis & Rosette & 34.99 & 4 & $<0.001$ \\
Cover of B. bicaule & Erect & 90.80 & 4 & $<0.001$ \\
Cover of G. verum & Erect & 79.00 & 4 & $<0.001$ \\
Cover of nariin ovs & - & 30.35 & 4 & $<0.001$ \\
Standing biomass & - & 48.20 & 4 & $<0.001$ \\
\hline Significant $P$ values $(<0.05)$ indicate that percent coverage for that category changed along the gradient.
\end{tabular}

Potentilla acaulis, and species with the tussock form included perennial grasses such as Stipa krylovii and P. attenuata. The coverage by nariin ovs, including C. duriuscula, F. rubra, $K$. macrantha, and C. squarrosa, tended to increase as the distance between the plots and the water point decreased (Figure 4; Table 2). The result of the Bonferroni multiple comparison showed that the coverage of nariin ovs at the 0.6-, 1.2-, and 1.8-km sites was significantly greater than the coverage at the $2.4-$ and $3.0-\mathrm{km}$ sites $(P<0.05)$.

In summary, lightly grazed sites contained abundant growth of tall forbs including $B$. bicaule and G. verum, as well as tall grasses such as S. krylovii. Such rich forb communities were replaced by short swards dominated by nariin ovs, including C. duriuscula, F. rubra, K. macrantha, and C. squarrosa, as grazing intensity increased (Figures 3 and 4; Table 2).

The standing biomass significantly decreased as the distance to the water point decreased (Figure 5; Table 2). The result of the Bonferroni multiple comparison showed that the plant biomass at the $0.6-$ and $1.2-\mathrm{km}$ sites was significantly smaller than that the 2.4- and $3.0-\mathrm{km}$ sites $(P<0.05)$. Biomass removal by livestock at the $0.6-\mathrm{km}$ site was significantly greater than that at the $3.0-\mathrm{km}$ site (Figure 6 ; Table 3 ). In contrast, productivity did not differ significantly between the two sites (Figure 6; Table 3).

$\mathrm{CP}$ amounts per plot did not differ significantly among the five distances (Figure 7; Table 3).

\section{Discussion}

According to Kakinuma et al. (2008), the pastoralists in northern Mongolia judge that pastures dominated by nariin ovs (narrow plants) are good for grazing livestock. We

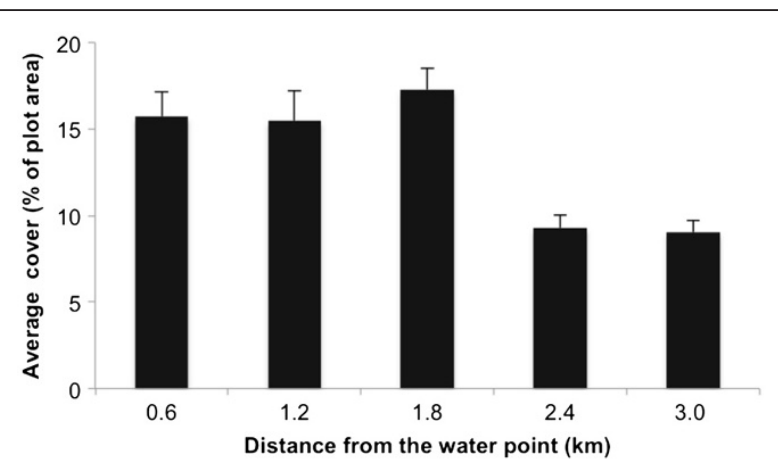

Figure 4 Coverage by nariin ovs (narrow plants) along the grazing gradient. Each bar represents the mean + standard error (SE). 


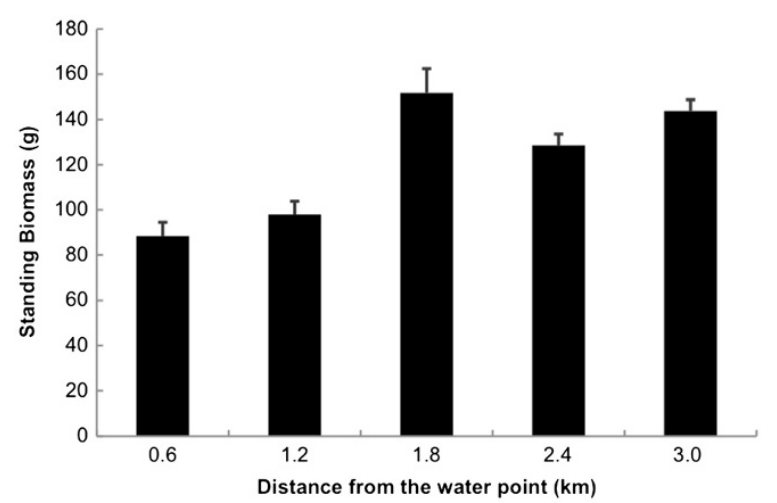

Figure 5 Standing biomass along the grazing gradient. Each bar represents the mean + SE.

tested the accuracy of this evaluation from the standpoint of plant ecology. As grazing intensity increased, communities dominated by branched and erect growth forms were replaced by short swards dominated by narrow plants (Figures 3 and 4; Table 2). These vegetation responses to grazing intensity were consistent with those reported by Fernandez-Gimenez et al. (2001), who carried out similar research in a mountainsteppe region of Mongolia.

Although the floristic composition changed and the standing biomass decreased as grazing intensity increased (Figure 5; Table 2), the plant productivity and $\mathrm{CP}$ amount were maintained (Figures 6 and 7; Table 3). These findings suggest high productivity and high protein concentrations in the plant body of low-growing graminoids (i.e. narrow plants). There seem to be two reasons for this. First, low-growing graminoids have the ability to compensate for the loss of biomass and are often able to tolerate grazing (McNaughton 1979). They can regrow better after grazing than plants with other growth forms because these species have shoot apices at the ground level and can tiller. Second, it is expected that much faeces would be deposited in places with high-density populations of livestock. This may have fertilizing effects, as was shown in eastern Botswana, where increased livestock density increased the nitrogen and other nutrients not only in the soil but also in the plant body because of the increased deposition of dung and urine (Tolsma et al. 1987). A similar phenomenon was observed in a very different ecosystem: in a marsh in Hudson Bay, Canada, Puccinellia phryganodes, a short-

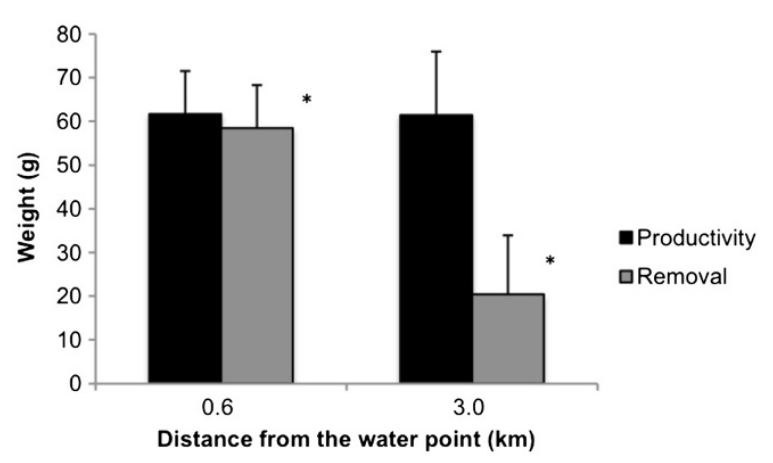

Figure 6 Plant productivity and grazing removal during one month at the 0.6 - and 3.0-km sites. Each bar represents the mean $+\mathrm{SE}$. The asterisk indicates statistical significance at $P<0.05$. 
Table 3 Results of ANOVA and Wilcoxon signed-rank tests to examine whether crude protein, biomass removal, or plant productivity changed along grazing gradient

\begin{tabular}{lllll}
\hline & $\boldsymbol{F}$ & $\boldsymbol{W}$ & $\boldsymbol{d . f .}$ & $\boldsymbol{P}$ \\
\hline Crude protein & 1 & - & 4 & 0.41 \\
Biomass removal & - & 49 & 1 & $<0.05$ \\
Productivity & - & 107.5 & 1 & 0.93 \\
\hline
\end{tabular}

A significant $P$ value $(<0.05)$ indicates that the value of that measurement changed along the gradient.

growing grass, was fertilized by defecation of snow geese (Chen caerulescens; Cargill and Jefferies 1984) and therefore had increased growth.

It is plausible that local pastoralists empirically know that heavily grazed narrow plants recover quickly and regard such low-growing graminoids as good plants for livestock grazing. Given the levels of livestock grazing that the pastoralists are accustomed to, our data indicate that the pastoralists' evaluation is reasonable in terms of livestock carrying capacity. The results of the present study should be applicable to other areas of the forest-steppe zone. However, because the precipitation variability, vegetation dynamics, and pastoralist mobility patterns in the steppe and desert-steppe are different from those in the forest-steppe, further studies are needed in order to apply these results to the steppe and desert-steppe.

Previous studies pointed out the different evaluations of rangeland conditions between researchers and pastoralists. The pastoralists' evaluation of rangeland conditions did not correspond with a grazing gradient, and they did not perceive as negative the simple species compositions and small biomass of grasslands under high grazing pressure, both of which are considered by researchers to be negative traits. In contrast, the present study showed that the plant productivity and nutritional values corresponded well with the TEK of the local people. This suggests that, when attempting to understand TEK, it is not sufficient to evaluate only the structural aspects of grasslands. Instead, researchers must also consider functional aspects, such as productivity and nutritional values. Evaluating TEK based on diversified criteria and the exchange of information between pastoralists and scientists should improve understanding and provide suggestions for future sustainable rangeland management (Briske et al. 2008, Reed et al. 2008).

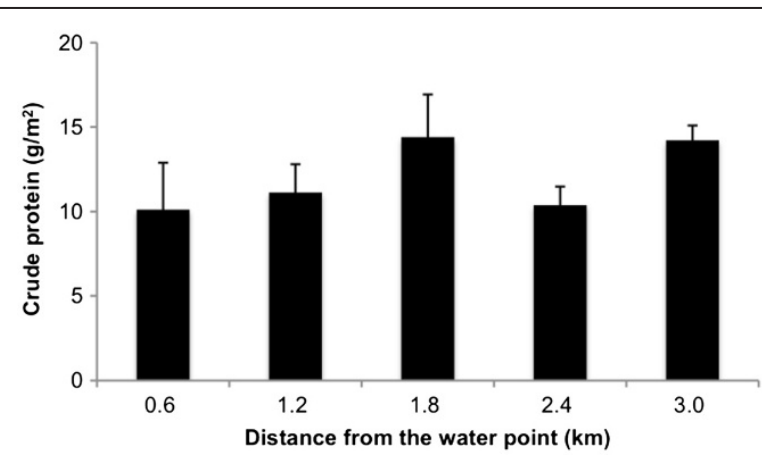

Figure 7 Estimated amounts of crude protein $\left(\mathrm{g} / \mathrm{m}^{2}\right)$ in plants growing along the grazing gradient. Each bar represents the mean $\pm \mathrm{SE}$. 


\section{Conclusions}

Our results support the knowledge of local pastoralists that narrow plants (low-growing graminoids) are productive and nutritious. However, it remains unclear whether the low-growing plant community can maintain its productivity for a long period and whether pastoralists consider future rangeland use when making current grazing decisions. Although McNaughton (1979) suggested that moderate grazing stimulates plant compensation for biomass loss as long as grazing is not too heavy, several studies reported no overcompensation when grazing intensity exceeded the plant growth rate (Leriche et al. 2003; Patton et al. 2007). For example, in a mixed-grass prairie of North Dakota grazed by livestock and wildlife, grass production was maintained under moderate grazing treatments, but decreased under heavy grazing treatments (Patton et al. 2007). In order to maintain the plant productivity at our study sites, future studies will be needed to identify the point along the grazing gradient where plant productivity is reduced. Through collaborative research, local knowledge and research-based ecological knowledge can be exchanged (Briske et al. 2008), with the aim of identifying and resolving the conflicting perceptions of ecological conditions often held by pastoralists and researchers (Fernandez-Gimenez 2000). Further assessments of the ecological status of Mongolian rangelands should provide a foundation for ecologically sound and culturally appropriate rangeland management.

\section{Competing interests}

The authors declare that they have no competing interests.

\section{Authors' contributions}

KK participated in the design of the study, carried out the vegetation sampling, and drafted the manuscript. ST participated in the design of the study and the vegetation sampling and helped to draft the manuscript. Both authors read and approved the final manuscript.

\section{Acknowledgements}

We thank the local pastoralists for their cooperation. We thank (The University of Tokyo) T. Sasaki and Y. Yoshihara (Tohoku University) for their helpful comments on an earlier draft and T. Iriki (Azabu University) for teaching us the methods and providing the laboratory for the nutrient measurements. We also thank J. Chuluun (pastoralist) and his five grandchildren for their assistance with the field survey. This research was partly supported by grants from the Asahi Breweries Foundation and the Sumitomo Foundation (2008-2010; project leader, S. Takatsuki).

\section{Author details}

'Department of Ecosystem Studies, Graduate School of Agricultural and Life Sciences, University of Tokyo, 1-1-1 Yayoi, Bunkyo-ku, Tokyo 113-8657, Japan. ${ }^{2}$ Laboratory of Wildlife Ecology and Conservation, School of Veterinary Medicine, Azabu University, 1-17-71, Fuchinobe, Chuo-ku, Sagamihara, Kanagawa 252-5201, Japan.

Received: 9 May 2012 Accepted: 24 September 2012

Published: 14 November 2012

\section{References}

Andrew, M.H. 1988. Grazing impact in relation to livestock watering points. Trends Ecology and Evolution 3: 336-339. Berkes, F. J. Colding, and C. Folke. 2000. Rediscovery of traditional ecological knowledge as adaptive management. Ecological Applications 10: 1251-1262.

Briske, D.D. B.T. Bestelmeyer, M. Fernandez-Gimenez, and M. Stafford-Smith. 2008. Information technologies for rangeland monitoring: what do they need to address? Proceedings of the XXI International Grassland Congress and VIII International Rangelands Congress, 29 June-5 July 2008, 633-637. Hohhot, China: Guangdong People's Publishing House.

Cargill, S.M. and R.L. Jefferies. 1984. The effects of grazing by lesser snow geese on the vegetation of a sub-arctic salt marsh. Journal of Applied Ecology 21: 669-686.

Ellis, J.E. 1995. Climate variability and complex ecosystem dynamics: implication for pastoral development. In Living with uncertainty. New directions in pastoral development in Africa, ed. I. Scoones, 37-46. London: Intermediate Technology Publications.

Fernandez-Gimenez, M.E. 2000. The role of Mongolian nomadic pastoralists' ecological knowledge in rangeland management. Ecological Applications 10: 1318-1326.

Fernandez-Gimenez, M.E. 2002. Spatial and social boundaries and the paradox of pastoral land tenure: a case study from postsocialist Mongolia. Human Ecology 30: 49-78. 
Fernandez-Gimenez, M. and B. Allen-Diaz. 2001. Vegetation change along gradients from water sources in three grazed Mongolian ecosystems. Plant Ecology 157: 101-118.

Gimingham, C.H. 1951. The use of life form and growth form in the analysis of community structure, as illustrated by a comparison of 2 dune communities. Journal of Ecology 39: 396-406.

Hilbig, W. 1995. The vegetation of Mongolia. Amsterdam: SPB Academic Publishing.

Humphrey, C. and D. Sneath. 1999. The end of nomadism? Society, state, and the environment in Inner Asia. Durham: Duke University Press.

Kakinuma, K. T. Ozaki, S. Takatsuki, and C. Jonjin. 2008. How pastoralists in Mongolia perceive vegetation changes caused by grazing. Nomadic Peoples 12: 67-73.

Katjiua, M. and D. Ward. 2007. Pastoralists' perceptions and realities of vegetation change and browse consumption in the northern Kalahari, Namibia. Journal of Arid Environments 69: 716-730.

Leriche, H. X. Le Roux, F. Desnoyers, D. Benest, G. Simioni, and L. Abbadie. 2003. Grass response to clipping in an African savanna: testing the grazing optimization hypothesis. Ecological Applications 13: 1346-1354.

McNaughton, S.J. 1979. Grazing as an optimization process: grass-ungulate relationships in the Serengeti. American Naturalist 113: 691-703.

McNaughton, S.J. D.G. Milchunas, and D.A. Frank. 1996. How can net primary productivity be measured in grazing ecosystems? Ecology 77: 974-977.

Milton, S.J. W.R.J. Dean, and R.P. Ellis. 1998. Rangeland health assessment: a practical guide for ranchers in arid Karoo shrublands. Journal of Arid Environments 39: 253-265.

Morinaga, Y. T. Ozaki, K. Kakinuma, S. Takatsuki, and C. Jonjin. 2008. Traditional knowledge of Mongolian pastoralists and scientific evidence - a case study at a forest-steppe in northern Mongolia. In Proceedings of the 6th International Grassland Congress and 8th International Rangeland Congress, vol. Volume 1, 867. Hohhot, China: Guangdong People's Publishing House.

Oba, G. and L.M. Kaitira. 2006. Herder knowledge of landscape assessments in arid rangelands in northern Tanzania. Journal of Arid Environments 66: 168-186.

Okayasu, T. M. Muto, U. Jamsran, and K. Takeuchi. 2007. Spatially heterogeneous impacts on rangeland after social system change in Mongolia. Land Degradation \& Development 18: 555-566.

Patton, B.D. X.J. Dong, P.E. Nyren, and A. Nyren. 2007. Effects of grazing intensity, precipitation, and temperature on forage production. Rangeland Ecology and Management 60: 656-665.

Reed, M.S. A.J. Dougill, and T.R. Baker. 2008. Participatory indicator development: what can ecologists and local communities learn from each other? Ecological Applications 18: 1253-1269.

Riney, T. 1982. Study and management of large mammals. Chichester: Wiley.

Sasaki, T. T. Okayasu, U. Jamsran, and K. Takeuchi. 2008. Threshold changes in vegetation along a grazing gradient in Mongolian rangelands. Journal of Ecology 96: 145-154.

Tolsma, D.J. W.H.O. Ernst, and R.A. Verwey. 1987. Nutrients in soil and vegetation around 2 artificial waterpoints in eastern Botswana. Journal of Applied Ecology 24: 991-1000.

doi:10.1186/2041-7136-2-23

Cite this article as: Kakinuma and Takatsuki: Applying local knowledge to rangeland management in northern Mongolia: do 'narrow plants' reflect the carrying capacity of the land?. Pastoralism: Research, Policy and Practice $20122: 23$.

\section{Submit your manuscript to a SpringerOpen ${ }^{\circ}$} journal and benefit from:

- Convenient online submission

- Rigorous peer review

- Immediate publication on acceptance

- Open access: articles freely available online

- High visibility within the field

- Retaining the copyright to your article

Submit your next manuscript at $\boldsymbol{\sim}$ springeropen.com 